\title{
PERHITUNGAN CHANGE ORDER PROYEK JALAN DI BANTEN
}

\author{
Mega Waty ${ }^{1}$, Hendrik Sulistio ${ }^{2}$ \\ ${ }^{1}$ Jurusan Teknik Sipil, Universitas Tarumanagara \\ Email: mega@ft.untar.ac.id \\ 2 Jurusan Teknik Sipil, Univeristas Tarumanagara \\ Email: hendriks@ft.untar.ac.id
}

Masuk: 13-12-2019, revisi: 07-07-2020, diterima untuk diterbitkan: 22-08-2020

\begin{abstract}
ABSTRAK
Change order mencakup sejumlah varian dalam ruang lingkup pekerjaan yakni jumlah material, kesalahan desain, dan perubahan harga. Makalah ini membahas change order dalam proyek konstruksi jalan di Banten dengan menyelidiki penyebab, mempelajari efeknya pada proyek, dan mengidentifikasi pihak-pihak yang diuntungkan. Penelitian menggunakan lima proyek jalan sebagai studi kasus aktual dan Kuisoner menggunakan Skala Likert Enam poin. Untuk mengetahui peringkat faktor yang mempengaruhi penyebab change order, efek change order dan faktor yang diuntungkan dari change order digunakan perhitungan Relative Importance Index (RII). Efek terpenting dari change order pada proyek ditemukan adalah penundaan jadwal, pembengkakan biaya dan perselisihan. Kontraktor selaku pihak yang paling diuntungkan dari change order diikuti oleh konsultan dan kemudian owner.
\end{abstract}

Kata kunci: change order; proyek jalan; Relative Importance Index (RII)

\begin{abstract}
Change orders include a number of variants in the scope of work namely the amount of material, design errors, and price changes. This paper discusses change orders in a road construction project in Banten by investigating the causes, studying their effects on the project, and identifying the beneficiaries. The study used five road projects as actual case studies and the questionnaire used a six-point Likert Scale. To determine the ranking of factors that influence the causes of change orders, the effect of change orders and the factors that benefit from change orders are used the Relative Importance Index (RII) calculation. The most important effects of change orders on projects are found to be schedule delays, cost overruns and disputes. The contractor as the party that benefits the most from the change order is followed by the consultant and then the owner.
\end{abstract}

Keywords: change order; road project; Relative Importance Index (RII)

\section{PENDAHULUAN}

Perubahan selama pembangunan proyek tidak dapat dihindari pada sebagian besar proyek konstruksi, sehingga Change Order digunakan untuk memperbaiki atau memodifikasi desain asal atau ruang lingkup pekerjaan. Koreksi atau modifikasi dilakukan karena berbagai alasan termasuk perubahan dalam ruang lingkup yang dibuat oleh Pemilik dan sebagai hasil dari permintaan perubahan yang dibuat oleh konsultan karena kesalahan desain atau temuan baru. Kontraktor menggunakan interpretasi klausul kontrak yang berbeda atau merubah desain awal untuk meningkatkan margin keuntungan. Kebanyakan Change Order terjadi selama periode konstruksi menjadi penyebab utama dari perpanjangan waktu dan peningkatan biaya, gangguan, dan perselisihan. Belum ada metode unik yang tersedia untuk menghindari atau mengelola Change Order secara efektif. Pendekatan konvensional adalah dengan memasukkan persentase dari biaya proyek sebagai kontingensi dalam anggaran kontrak proyek sehingga berdampak pada pembengkakan biaya. 
Kaming et al. (1997) mempelajari faktor-faktor yang mempengaruhi tiga puluh satu proyek bertingkat tinggi di Indonesia dan menemukan bahwa perubahan desain adalah salah satu faktor terpenting yang menyebabkan perpanjangan waktu. Pada kasus lain, Al-Momani (2000) menemukan pengguna perubahan adalah salah satu penyebab utama keterlambatan dalam 130 proyek publik di Jordan. Goudreau (2001) melaporkan lima elemen kunci yang membebani proyek; yakni pembayaran, wewenang, mengubah urutan, jadwal pekerjaan, dan dokumen kontrak.

Memon (2004) membagi penyebab keterlambatan menjadi dua kategori besar, yaitu keterlambatan excusable dan keterlambatan yang tidak bisa digunakan. Penundaan jadwal yang bisa dimaafkan lebih berorientasi pada Pemilik atau konsultan, sedangkan penundaan waktu yang tidak dapat dimaafkan bila terjadi dengan kontraktor. Perubahan desain menyebabkan keterlambatan yang dapat dimaafkan. Acharya et al. (2006) melakukan survey lapangan dan mengidentifikasi enam faktor yang saling bertentangan terkait konstruksi di Korea. Berdasarkan studi Arun dan Rao (2007), Change Order merupakan faktor ketiga yang menyebabkan konflik dalam proyek konstruksi. Arun dan Rao (2007) melaporkan perubahan dalam desain serta cacat dan koreksi dalam desain sebagai faktor yang mengakibatkan pembengkakan biaya dan penundaan waktu.

Assaf dan Al-Hejji (2006) melakukan survei lapangan pada kinerja waktu konstruksi yang berbeda proyek di Arab Saudi. Mereka mengidentifikasi 73 penyebab keterlambatan dalam 76 proyek yang disurvei, tetapi penyebab paling umum keterlambatan yang diidentifikasi oleh ketiga pihak yakni Pemilik, konsultan, dan kontraktor adalah Change Order. Ibbs (1997) menemukan bahwa perubahan telah terjadi efek luar biasa pada kinerja proyek konstruksi dan seluruh industri telah dikembangkan untuk melawan perubahan pesanan 'klaim dan perselisihan. Hanna et al. (2002) menyatakan bahwa semakin banyak varian dalam suatu proyek, semakin tinggi probabilitas proyek untuk menjadi berdampak dan memiliki kerugian produktivitas yang signifikan. Mereka menghitung probabilitas 54,8\% bahwa proyek akan terkena dampak varian. Chan dan Kumaraswamy (1997) membuat perbandingan studi tentang penyebab penundaan waktu dalam pembangunan proyek di Hong Kong dan membandingkan hasilnya dengan yang ditemukan di Arab Saudi dan Nigeria. Mereka menemukan bahwa perubahan yang diprakarsai Pemilik dan Change Order adalah salah satu penyebab terpenting dari keterlambatan waktu. Lee (2008) mempelajari data 161 proyek transportasi yang sudah selesai. Hasil penelitian menunjukkan bahwa $95 \%$ dan $100 \%$ proyek jalan dan kereta api, masing-masing, memiliki pembengkakan biaya maksimum sebesar 50\%. Penyebab utama dari pembengkakan biaya ditemukan menjadi perubahan ruang lingkup, keterlambatan selama konstruksi, estimasi yang tidak beralasan, penyesuaian biaya proyek, dan tidak ada penggunaan praktis system earned value manajemen.

Perubahan dalam konstruksi proyek jalan di Provinsi Banten menggambarkan sejumlah kondisi dan syarat dalam ruang lingkup proyek, perbedaan utama dalam hal kuantitas, perubahan dalam desain, dan keterlambatan waktu.

\section{Rumusan masalah}

a. Apakah efek perhitungan change order proyek jalan di Banten

b. Apakah penyebab change order proyek jalan di Banten

c. Apakah pihak yang diuntungkan pada change order proyek jalan di Banten 
Berdasarkan rumusan masalah tersebut, penelitian ini bertujuan untuk menyelidiki efek dan penyebab dari Change Order serta pihak yang diuntungkan dalam lima proyek di Banten yang digunakan sebagai studi kasus.

\section{STUDI KASUS}

\section{a. Studi Kasus No. 1: Proyek Jalan 1}

Pada proyek jalan 1 terjadi pengurangan panjang jalan beton, sehingga ditambahkan pekerjaan aspal, marka jalan termoplastik dan rambu jalan tunggal pada segmen lain. Terdapat perubahan total pekerjaan sebesar $25,27 \%$ pada proyek jalan 1 . Proyek Jalan Nomor 1 memiliki nilai kontrak sebesar Rp. 17.891.881.499,20 dan tidak ada penambahan dana pada proyek, namun terdapat perpanjangan waktu sebesar 5,80\%.

\section{b. Studi Kasus No. 2: Proyek Jalan 2}

Pada proyek jalan 2 mengalami dua kali perubahan Change Order. Proyek jalan 2 terbagi menjadi dua bagian besar yakni rehab mayor dan pekerjaan rehab minor.

- Change Order No: 1 atau biasanya disebut addendum 1, yaitu:

Pekerjaan rehab mayor mengalami pengurangan volume pekerjaan drainase jalan dan pengurangan pada pekerjaan pelebararan perkerasan dan bahu jalan. Demikian pula terjadi pengurangan pekerjaan perkerasan berbutir dan terjadi pula pengurangan pekerjaan perkerasan aspal pada jalan aspal dan pengurangan panjang jalan beton. Pada Proyek jalan 2 terjadi pengurangan panjang jalan beton, jalan aspal dan drainase jalan, sehingga terjadi penambahan pada pekerjaan minor seperti campuran aspal dan patok kilometer dan median jalan.

Pada pekerjaan rehab minor juga mengalami penambahan baja tulangan dan penambahan marka termoplastik dan terdapat pengurangan pekerjaan aspal. Change Order Nomor 1 tidak terdapat penambahan dana dan yang terjadi hanya balance budget.

- Change Order No: 2 atau biasanya kita sebut addendum 2 yakni:

Pada pekerjaan Rehab mayor terdapat penambahan panjang jalan aspal dan penambahan jalan beton. Pada rehab minor terdapat penambahan pelebaran bahu jalan yaitu penambahan jalan aspal.

Terjadi penambahan dana pada proyek jalan dua dari kontrak asal Rp. 21.185.357.000,00 menjadi Rp. 22.752.011.000,00 atau sebesar 7,3 \% dari nilai kontrak. Terdapat perubahan total pekerjaan sebesar 38,5\%. Addendum 1 dikeluarkan karena kesalahan desain dalam perubahan panjang jalan beton dan jalan aspal. Kelompok kedua termasuk varian yang dikeluarkan karena persyaratan ruang lingkup tambahan, yang mencakup penambahan pembangunan rehab minor proyek jalan tersebut. Tipe pertama bisa dihindari dengan pengukuran yang tepat dan survey penyelidikan tanah dan survey lapangan yang tepat.

Tipe kedua bisa diminimalkan oleh ketepatan perencanaan yang tepat dan pentahapan proyek yang tepat. Hal ini menjelaskan bahwa konsultan mempunyai kontribusi yang besar kepada Pemilik. Selain kenaikan biaya, terjadi juga perpanjangan waktu sebesar 9,3\%. Di Banten, masalah-masalah tersebut diatasi dengan meminta dana tambahan dari otoritas pemerintah terkait. 


\section{c. Studi Kasus No. 3: Proyek Jalan 3}

Lingkup pekerjaan asli untuk proyek jalan 3 terdiri dari pekerjaan rehabilitasi jalan sepanjang $7 \mathrm{Km}$ dan panjang rutin jalan sepanjang 49,59 Km. Addendum nomor 1 terjadi karena terdapat penambahan pekerjaan drainase jalan berupa penambahan gorong-gorong saluran dan pengurangan pekerjaan tanah berupa galian baik galian biasa maupun galian perkerasan berbutir. Pada Proyek jalan 3 terjadi penambahan panjang jalan beton, penambahan waktu sebesar 5,8 \%. Nilai kontrak pada proyek jalan 3 sebesar Rp. 11.790.233.000,00 dan hanya satu kali perubahan namun tidak terjadi penambahan dana (Balance Budget). Konsultan mendesain ulang sehingga terjadi perubahan yang besar dengan total perubahan sebesar $94,46 \%$.

\section{d. Studi Kasus No. 4: Proyek Jalan 4}

Lingkup pekerjaan terdiri dari rehabilitasi jalan dengan nilai kontrak Rp. 2.647.761.000,00 yang meliputi pekerjaan drainase jalan dan pekerjaan tanah dan pekerjaan struktur. Addendum (Change Order) Nomor 1 menyatakan penambahan saluran drainase dan mengurangi pekerjaan tanah dan pengurangan panjang jalan beton dan penambahan dinding penahan tanah dengan pasangan batu. Berdasarkan hal ini, konsultan mendesain ulang penampang jalan hingga terjadi penambahan dana sebesar 9,16\% menjadi Rp. 2.890.502.000,00 dan juga terjadi penambahan waktu sebesar $9,30 \%$. Secara umum, total perubahan proyek sebesar 6,57\%.

Modifikasi menghasilkan Change Order No. 1. Efek bersih dari Change Order No. 1 memperbesar 9,16\% dari nilai kontrak, sehingga memberikan hak kepada kontraktor untuk mengklaim harga unit baru pada jumlah dinding penahan tanah. Risiko-risiko ini dapat diminimalisir dengan menerapkan inspeksi dan desain teknik yang tepat.

\section{e. Studi Kasus No. 5: Proyek Jalan Nomor 5.}

Proyek jalan nomor 5 ini merupakan proyek rehabilitasi Jalan Lingkup pekerjaan terdiri dari pekerjaan struktur, pekerjaan perkerasan aspal, perkerasan beton semen, drainase, dan pekerjaan tanah.

Change Order nomor 1 menjelaskan tentang penambahan pekerjaan pekerjaan galian tanah dan pengurangan pekerjaan parit dan gorong gorong. Penambahan pekerjan penyiapan badan jalan dan penimbunan badan jalan juga mengurangi pelebaran bahu jalan dan pengurangan panjang jalan aspal. Di sisi lain terdapat penambahan panjang jalan beton. Change Order No. 1. menyebabkan terjadinya balance budget dan tidak ada penambahan waktu. Change Order No. 2 menyebabkan penambahan pekerjaan drainase dan pekerjaan tanah dan pekerjaan aspal setelah konsultan mendesain ulang dengan melakukan survey lapangan dan survey topografi maka dilakukan perhitungan ulang terhadap anggaran biaya sehingga terjadi waktu sebesar 11,66 \% dan pertambahan biaya 9,5\% sebesar dengan total perubahan sebesar 19,40\%. Rekapitulasi hasil perubahan masing masing studi kasus dapat dilihat pada Tabel 1 untuk perubahan nilai kontrak dan perpanjangan waktu dapat dilihat pada Tabel 2 dan total perubahan proyek di Tabel 3.

Tabel 1. Total Nilai Change Order Kontrak Studi Kasus Proyek Provinsi Banten

\begin{tabular}{llrrr}
\hline No & Paket & \multicolumn{1}{l}{ Kontrak } & Kontrak Addendum & \% dari nilai kontrak \\
\hline 1 & Jalan 1 & 17.891 .881 .000 & 17.891 .881 .000 & Tetap \\
\hline 2 & Jalan 2 & 21.185 .357 .000 & 22.752 .011 .000 & 7,30 \\
\hline 3 & Jalan 3 & 11.790 .233 .000 & 11.790 .233 .000 & Tetap \\
\hline 4 & Jalan 4 & 2.647 .761 .000 & $2,890.502 .000$ & 9,16 \\
\hline 5 & Jalan 5 & 7.322 .434 .000 & 8.022 .434 .000 & 9,50 \\
\hline
\end{tabular}


Tabel 2. Total perubahan waktu kontrak studi kasus Proyek Provinsi Banten

\begin{tabular}{|c|c|c|c|c|}
\hline No & Paket & Waktu pelaksanan & Pertambahan waktu & $\begin{array}{l}\% \text { dari } \\
\text { nilai } \\
\text { kontrak }\end{array}$ \\
\hline 1 & Jalan 1 & 240 & 14 & 5,80 \\
\hline 2 & Jalan 2 & 300 & 28 & 9,30 \\
\hline 3 & Jalan 3 & 240 & 14 & 5,80 \\
\hline 4 & Jalan 4 & 150 & 14 & 9,30 \\
\hline 5 & Jalan 5 & 240 & 28 & 11,66 \\
\hline
\end{tabular}

Tabel 3. Perubahan pekerjaan absolut Total Proyek Banten

\begin{tabular}{rcr}
\hline No & Nama Proyek & \multicolumn{2}{c}{$\begin{array}{l}\text { Perubahan } \\
\text { total }(\%)\end{array}$} \\
\hline 1 & Jalan 1 & 25,27 \\
\hline 2 & Jalan 2 & 38,50 \\
\hline 3 & Jalan 3 & 94,46 \\
\hline 4 & alan 4 & 6,56 \\
\hline 5 & Jalan 5 & 19,40 \\
\hline
\end{tabular}

Berdasarkan studi kasus yang dibahas di atas, hal tersebut menjelaskan bahwa Change Order dalam proyek konstruksi sebagian besar menyebabkan pembengkakan biaya dan penambahan waktu. Kuesioner adalah salah satu alat yang digunakan untuk mendapatkan umpan balik dari Pemilik, konsultan dan kontraktor untuk mengetahui penyebab dan pihak-pihak yang diuntungkan untuk Change Order yang dikeluarkan dalam proyek konstruksi jalan di Banten.

\section{METODOLOGI PENELITIAN}

Kuesioner mencakup beberapa pernyataan yang dibagi menjadi empat bagian. Bagian I dan II membahas penyebab pada proyek konstruksi. Kuesioner menggunakan Skala Likert Enam poin mulai dari 1 sangat tidak setuju hingga angka 6 tidak ada komentar diadopsi untuk menyatakan pendapat responden tentang penyebab. Solusi yang disarankan oleh penulis diberikan berdasarkan pengetahuan yang diperoleh dari lima studi kasus. Penyebab dikategorikan ke dalam empat kelompok: berhubungan dengan owner, terkait dengan konsultan, terkait dengan kontraktor, dan lainnya. Kuesioner dibagikan kepada owner, kontraktor, dan konsultan yang terlibat dalam tipe dan sejenis ukuran proyek yang disajikan dalam studi kasus di atas. Seluruh owner dipilih dari instansi pemerintah karena studi kasus yang diambil adalah proyek pemerintah. Pernyataan kuesioner disusun berdasarkan pengalaman dan diskusi dengan berbagai pihak serta mirip dengan pernyataan yang disajikan dalam berbeda literatur. Kuisioner dibagikan secara bersamaan dengan waktu untuk mengumpulkan semua tanggapan. Untuk memastikan representasi jawaban dengan baik, maka hanya digunakan satu pengaturan kuesioner yang diberikan kepada setiap owner, konsultan, dan kontraktor.

Untuk mengetahui peringkat faktor yang mempengaruhi penyebab change order, efek change order dan faktor yang diuntungkan dari change order digunakan perhitungan Relative Importance Index (RII).

Relative Importance Index dapat dihitung menggunakan rumus dibawah ini:

$$
\mathrm{RII}(\%)=\frac{6 \mathrm{n} 6+5 \mathrm{n} 5+4 \mathrm{n} 4+3 \mathrm{n} 3+2 \mathrm{n} 2+\mathrm{n} 1}{\mathrm{~W}(\mathrm{n} 6+\mathrm{n} 5+\mathrm{n} 4+\mathrm{n} 3+\mathrm{n} 2+\mathrm{n} 1)} \times 100
$$


Keterangan:

n6 : Jumlah responden yang memilih skala 6

n5 : Jumlah responden yang memilih skala 5

n4 : Jumlah responden yang memilih skala 4

n3 : Jumlah responden yang memilih skala 3

n2 : Jumlah responden yang memilih skala 2

n1 : Jumlah responden yang memilih skala 1

W : Skala terbesar dalam skala likert

Analisis responden kuesioner terutama dilakukan oleh menghitung RII. RII digunakan sebagai teknik peringkat untuk setiap pernyataan untuk membandingkan tanggapan yang diterima dari satu pihak yakni pihak kontraktor yang mengembalikan kuesioner sebanyak 30 responden sedangkan pihak owner dan konsultan mengembalikan kuesioner tapi dalam jumlah yang sedikit sehingga tidak dapat dipergunakan. Ini dilakukan untuk setiap bagian dari kuesioner yaitu, penyebab, efek, dan pihak yang diuntungkan karena change order.

\section{HASIL DAN PEMBAHASAN}

Diskusi tentang penyebab utama varian, efek utama varian pada proyek dan pihak-pihak penerima keuntungan karena change order disajikan di bawah ini.

\section{Penyebab change order}

Tabel 4 menyajikan RII dan peringkat masing-masing penyebab berdasarkan tanggapan diterima dari pihak kontraktor.

Tabel 4. Penyebab dan Peringkat Masing Masing Penyebab

\begin{tabular}{|c|c|c|}
\hline Penyebab ( Alnuami et al.,2020) & RII & Rank \\
\hline Pemilik menginstruksikan pekerjaan tambahan & 92,778 & 5 \\
\hline Pemilik menginstruksikan modifikasi untuk mendesain & 96,111 & 4 \\
\hline Tidak tersedianya manual konstruksi dan prosedur untuk konstruksi proyek di Banten & 83,889 & 7 \\
\hline $\begin{array}{l}\text { Tidak tersedianya lisensi teknik untuk insinyur di Banten untuk menjaga kualitas layanan } \\
\text { konsultasi }\end{array}$ & 83,333 & 8 \\
\hline Komunikasi yang buruk antara unit pemerintah terkait dan pemilik & 89,444 & 6 \\
\hline Tidak tersedianya perencanaan proyek secara keseluruhan & 96,667 & 3 \\
\hline Periode desain yang tidak realistis & 97,778 & 1 \\
\hline Jadwal konstruksi yang tidak realistis & 67,222 & 13 \\
\hline Pemilik gagal membuat keputusan atau meninjau dokumen pada waktu yang tepat & 66,667 & 14 \\
\hline Biaya konsultasi rendah atau desainer yang kurang berpengalaman & 97,222 & 2 \\
\hline Tidak tersedianya catatan proyek serupa di Banten & 83,333 & 9 \\
\hline $\begin{array}{l}\text { Kegagalan oleh konsultan untuk memberikan informasi yang memadai dan jelas dalam } \\
\text { dokumen tender }\end{array}$ & 66,667 & 14 \\
\hline Pertumbuhan alami proyek tidak diantisipasi pada tahap desain & 67,222 & 13 \\
\hline Kebutuhan pemilik selama tahap desain tidak jelas atau tidak didefinisikan dengan baik & 67,222 & 13 \\
\hline $\begin{array}{l}\text { Kontraktor menggunakan area abu-abu dalam kondisi umum dan meminta varian pada } \\
\text { kontrak }\end{array}$ & 67,222 & 13 \\
\hline Kesalahan desain & 66,667 & 14 \\
\hline Kriteria desain dan konstruksi sudah usang dan tidak sesuai dengan teknologi konstruksi saat ini & 67,222 & 13 \\
\hline Kontraktor menyalahgunakan instruksi variasi & 67,222 & 13 \\
\hline Tidak tersedianya insinyur yang berkualitas dari sisi pemilik & 66,667 & 14 \\
\hline
\end{tabular}




\begin{tabular}{lll}
\hline Konsultan tidak terbiasa dengan peraturan dan izin konstruksi di Banten & 81,667 & 10 \\
\hline Keputusan sepihak yang dibuat oleh pemilik tanpa pertimbangan yang tepat untuk kontrak & 77,778 & 12 \\
\hline Pengawas konsultan tidak memiliki pengalaman kolektif tentang proyek konstruksi di Banten & 66,667 & 14 \\
\hline Kegagalan oleh konsultan untuk melakukan desain dan pengawasan secara efektif & 66,667 & 14 \\
\hline Manajemen proyek yang buruk oleh kontraktor & 80,556 & 11 \\
\hline
\end{tabular}

Kemudian diekstrak menjadi 5 penyebab terbesar berdasarkan RII tertinggi yakni terdapat pada Tabel 5.

Tabel 5. Penyebab Terbesar Change order Berdasarkan RII

\begin{tabular}{lrr}
\hline Penyebab & RII & Peringkat \\
\hline Periode design yang tidak realistik & 97.78 & 1 \\
\hline Biaya konsultasi rendah atau desainer yang kurang berpengalaman & 97.22 & 2 \\
\hline Tidak Tersedianya perencanaan proyek secara keseluruhan & 96.67 & 3 \\
\hline Pemilik menginstruksikan modifikasi untuk desain & 96.11 & 4 \\
\hline Pemilik menginstruksikan pekerjaan tambahan & 92.77 & 5 \\
\hline
\end{tabular}

Penyebab tertinggi Change order adalah periode design yang tidak realistic. Konsultan tidak mendapat kesempatan mengerjakan dengan waktu yang cukup sehingga hasilnya tidak realistik, biaya konsultansi rendah karena konsultan kurang berpengalaman. Begitu pula halnya dengan pemilik, karena pemilik yang menginstruksikan modifikasi dan menginstruksi pekerjaan tambahan.

\section{Efek change order}

Efek atau akibat change order yang terbesar berdasarkan kuesioner adalah sebagai berikut:

Tabel 6. Ranking Efek dari Change order

\begin{tabular}{lrr}
\hline Efek & RII & Peringkat \\
\hline Tunda tanggal penyelesaian proyek & 90 & 1 \\
\hline Pembengkakaan biaya & 89,4 & 2 \\
\hline Change order menghasilkan klaim dan perselisihan & 85 & 3 \\
\hline Mempengaruhi kinerja dan moral kerja & 83,89 & 4 \\
\hline Sebagian besar kontraktor mengeluarkan biaya tambahan & 83,33 & 5 \\
\hline Mempengaruhi kualitas & 81,67 & 6 \\
\hline
\end{tabular}

Tabel 6 menyajikan pendapat responden secara keseluruhan tentang efeknya Change order. "Tanggal tunda penyelesaian proyek" adalah efek paling penting dari variasi RII $=90$. Hal tersebut akan diharapkan karena perubahan sebagian besar akan menghasilkan revisi rencana, penambahan pekerjaan, lebih banyak waktu untuk pengambilan keputusan, materi re-sourcing, dan sebagainya.

Efek penting kedua ditemukan "pembengkakan biaya" dengan RII dari 89,40. Ini salah satunya efek utama, sehingga pembengkakan biaya sering terjadi terutama di negara-negara berkembang, seperti banyak dari varian tidak dipelajari dengan baik. Efek penting ketiga yakni change order menyebabkan kebingungan dan gangguan,yang mengakibatkan klaim dan perselisihan, khususnya dalam kasus memperkenalkan materi baru atau aktivitas kerja yang tidak dalam kontrak aslinya. 
Efek ke empat yakni change order mempengaruhi kinerja dan modal kerja dengan RII = 83,39 demikian pula kontraktor mengeluarkan biaya tambahan ini yang menjadi efek yang ke lima dengan RII = 83,33.

Tabel 7. Pihak yang mendapat Keuntungan Karena Change Order

\begin{tabular}{lcr}
\hline Pihak yang mendapat keuntungan & RII & Peringkat \\
\hline $\begin{array}{l}\text { Kontraktor akan mendapat manfaat paling } \\
\text { banyak dari change order }\end{array}$ & 91,11 & 1 \\
\hline $\begin{array}{l}\text { Konsultan akan mendapat manfaat paling } \\
\text { banyak dari change order }\end{array}$ & 89,44 & 2 \\
\hline $\begin{array}{l}\text { Pemilik akan mendapat manfaat paling banyak } \\
\text { dari change order }\end{array}$ & 86,11 & \\
\hline $\begin{array}{l}\text { Tak satupun dari ketiga pihak akan mendapat } \\
\text { manfaat dari change order }\end{array}$ & 83,88 & \\
\hline
\end{tabular}

\section{Pihak yang mendapat keuntungan dari change order}

Menurut peringkat pada Tabel 7, pihak pertama yang diuntungkan dari change order adalah kontraktor RII $=91,11$, manfaat kedua pihaknya adalah konsultan $\mathrm{RII}=89,44$, dan yang paling tidak diuntungkan pihak adalah klien RII $=86,11$. Studi ini juga menunjukkan hanya sedikit orang yang percaya bahwa tidak ada yang mendapat manfaat dari change order $\mathrm{RII}=83,88$. Hal tersebut berarti seseorang diuntungkan change order. Menurut pendapat penulis, semua pihak mendapat manfaat dari change order. Kontraktor mendapat manfaat karena mendapat dana peningkatan pekerjaan termasuk harga satuan, perpanjangan waktu, varian dalam jumlah tanpa persaingan dari kontraktor lain.

Konsultan mendapat manfaat karena pembayaran terjamin untuk perpanjangan waktu dan modifikasi desain. Manfaat pemilik atau owner karena dia akhirnya menerima proyek dengan lebih sedikit masalah setelah koreksi/ modifikasi. Bertentangan dengan hasil, itu juga keyakinan penulis bahwa konsultanlah yang diuntungkan yang paling. Ini karena tingkat risiko yang rendah dan pembayaran biaya dijamin dalam banyak kasus. Keyakinan tersebut diperkuat oleh hasil yang disajikan pada Tabel 7, di mana yang paling banyak lima faktor penting yang menyebabkan change order hanya satu (peringkat 4) secara langsung terkait dengan konsultan. Hal tersebut menunjukkan bahwa sebagian besar change order tidak terkait dengan konsultan. Oleh karena itu, konsultan akan dibayar untuk perpanjangan waktu dan modifikasi desain. Bahkan dalam kasus menghukum kontraktor karena keterlambatan, pembayaran untuk konsultan akan dijamin.

\section{KESIMPULAN DAN SARAN \\ Kesimpulan}

Kesimpulan yang didapat dari penelitian diatas adalah:

a. Efek Change Order dari perhitungan Change Order proyek jalan di Banten adalah:

- Tunda tanggal penyelesaian proyek.

- Pembengkakan biaya.

- Change Order menghasilkan klaim dan perselisihan.

- Mempengaruhi kinerja dan moral kerja.

- Sebagian besar kontraktor mengeluarkan biaya tambahan.

b. Penyebab Change Order proyek jalan di Banten adalah:

- Periode desain yang tidak realistis.

- Biaya konsutan rendah atau desainer yang kurang berpengalaman. 
- Tidak tersedianya perencanaan proyek secara keseluruhan.

- Pemilik menginstruksikan modifikasi untuk desain.

- Pemilik menginstruksikan pekerjaan tambahan.

c. Pihak yang diuntungkan karena Change Order adalah kontraktor.

\section{Saran}

Saran yang dianjurkan:

a. Mengurangi Change Order dengan lebih memperhatikan periode design dan biaya konsultan yang lebih diperhatikan.

b. Mengurangi efek Change Order dengan lebih memperhatikan tanggal pelaksanaan proyek dan biaya yang dianggarkan.

\section{REFERENSI}

Acharya N. K., Lee Y. D., and Im H. M. (2006). "Conflicting factors in construction projects: Korean perspective." Eng., Construct., Archit. Manage., 13(6), 543-566.

Alnuaimi, A.S. \& Taha, R.A \% Mohsin, M.A.\& HArthi Ali S. Al. (2010) "Causes, Effect, Benefits, and Remedies of Change Orders on Public Construction Projects in Oman ", Journal of Construction Engineering and Management, Vol 136 (5),615-622

Al-Momani A.H. (2000). "Construction delay: A quantitative analysis." Int. J. Proj. Manage., 18(1), 51-59.

Arun, C., and Rao, B. N. (2007). "Knowledge based decision support tool for duration and cost overrun analysis of highway construction projects." J. Inst. Eng. (India), Part AG, 88, 27-33.

Assaf, S. A., and Al-Hejji, A. (2006). "Causes of delay in large construction projects." Int. J. Proj. Manage., 24, 349-357.

Chan, D. W. M., and Kumaraswamy, M. M. (1997). "A comparative study of causes of time overruns in Hong Kong construction projects." Int. J. Proj. Manage., 15(1), 55-63.

Goudreau, H. (2001). "The five key elements of a construction contract - Forget them and you are in trouble." _www.hgassociates.com/ articlecontracts.html__Feb. 18, 2010_.

Hanna, A. S., Camlic, R., Peterson, P. A., and Nordheim, E. V. (2002). "Quantitative definition of project impacted by Change Orders." J. Constr. Eng. Manage., 128(1), 57-64.

Ibbs, C. W. (1997). "Quantitative impacts of project change: Size issue." J. Constr. Eng. Manage., 123_3_, 308-311.

Kaming, P., Olomlaiye, P., Holt, G., and Harris, F. (1997). "Factors influencing construction time and cost overruns on high-rise projects in Indonesia." Constr. Manage. Econom., 15, 83-94.

Lee J. K. (2008). "Cost overrun and cause in Korean social overhead capital projects: Roads, rails, airports and ports." J. Urban Plann.Dev., 134(2), 59-62.

Memon, Z. A. (2004). "Remedial measure for delays at construction stage." J. Mehran Univ. (Eng. Technol.), 23(1), 9-20. 
